\title{
New regulatory tool for the conservation of the geological heritage in France: the Prefectural Decree of the Protection of the Geotope (APPG). Application and feedback in the Yvelines department (Paris basin, Île-de-France)
}

\author{
Elise Auberger ${ }^{1, *}$, Jean-Pierre Gély ${ }^{2}$ and Didier Merle ${ }^{3}$ \\ ${ }^{1}$ Sorbonne Université-CR2P-MNHN, CNRS, UPMC-Paris 6. Muséum national d'Histoire naturelle, Département Origines et \\ Évolution, 4 Place Jussieu, 75005 Paris, France \\ ${ }^{2}$ Université Panthéon-Sorbonnes-LAMOP-UMR 8589 CNRS, Paris 1, 17 rue de la Sorbonne, 75005 Paris, France \\ ${ }^{3}$ Sorbonne Université - CR2P-MNHN, CNRS, UPMC-Paris 6. Muséum national d'Histoire naturelle, Département Origines et \\ Évolution, 8 rue Buffon, 75005 Paris, France
}

Received: 3 October 2017 / Accepted: 20 January 2018

\begin{abstract}
In France, the conservation of geological heritage has a complex history that dates back to the middle of the 19th century. Two regulatory tools, "Site Classé", established in 1906, and Natural Reserves, created in 1976, have served to protect geological sites in the past. Nonetheless, these tools are long to implement vis-à-vis to the rapid destruction of geological objects in the French territory. Due to this juridical void, the state created in 2015 two prefectural decrees for the protection of geological sites of interest. These tools allow the Prefect to: (i) determine a departmental list of geological sites of importance; (ii) define appropriate regulations for their conservation through the Prefectural Decree of the Protection of the Geotope (APPG). Their decentralised legal proceedings appear to be easy to administer, as they only require the advice of regional and departmental commissions as well as some local stakeholders. Our article reports the first enactment of the APPG in France, in a peri-urban to urban area, the Yvelines department. By relying on the programmes of Strategy of Creation of Protected metropolitan Areas (SCAP) and the National Inventory of the Geological Heritage (INPG), two geological sites of international value threatened by anthropic activities were selected for the APPG: the Lutetian fossil sites of Grignon and the Ferme de l'Orme. If successfully enacted, the APPG could prove advantageous because it is a tool adapted to the protection of geological objects and to its socio-economic and environmental context. However, after almost two years, the proceedings of the APPG have not been finalised. Optional yet beneficial steps, as well as unforeseen requests, delayed the process considerably. Given that the APPG do not confer protection to the geological sites during this period, their efficacy must be questioned in a fast-evolving region where land pressure is high and geological sites disappear quickly. However, the French juridical system has improved in the recent years in that it encourages Earth Sciences specialists to form part of local consultative instances (CSRPN, CDNPS) and thereby influence the decisions concerning the protection of these highly threatened sites.
\end{abstract}

Keywords: Prefectural Decree of the Protection of the Geotope (APPG); geoheritage; regulatory protection; fossil site; Lutetian; peri-urban area

Résumé - Nouvel outil réglementaire pour la conservation du patrimoine géologique en France: l'Arrêté Préfectoral de Protection du Géotope (APPG). Application et évaluation dans les Yvelines (bassin de Paris, Île-de-France). En France, la préservation du patrimoine géologique est une histoire complexe débutant au milieu du $19^{\mathrm{e}}$ siècle. Deux outils réglementaires, l'outil « Site Classé » instauré en 1930 et les « Réserves naturelles » créées en 1976, ont servi à protéger les sites géologiques par le passé. Néanmoins ces outils, longs à mettre en place, peuvent être inadaptés face à la destruction rapide des richesses géologiques de notre territoire. Devant cette lacune juridique, l'État a créé en 2015, deux arrêtés préfectoraux relatifs à la protection des sites d'intérêts géologiques. Ces outils permettent au Préfet de : (i)

*Corresponding author: aubergerelise@gmail.com 
déterminer une liste départementale des sites géologiques considérés comme majeurs; (ii) définir une réglementation nécessaire à leur conservation grâce à l'Arrêté Préfectoral de Protection du Géotope (APPG). Leur procédure d'instruction décentralisée semble rapide à administrer car elle requiert de simples avis de conseils régionaux et départementaux ainsi que de quelques acteurs locaux. Notre article rapporte la première application de l'APPG en France, dans un département situé en milieu urbain à péri-urbain, les Yvelines. Grâce aux programmes de Stratégie de Création d'Aires protégées (SCAP) et à l'Inventaire National du Patrimoine Géologique (INPG), deux sites de valeur internationale fortement menacés par l'Homme ont été sélectionnés pour l'APPG : les gisements lutétiens de Grignon et de la Ferme de l'Orme. Cette étude reconnaît les avantages qu'apporte cet outil en permettant une protection adaptée aux objets géologiques et à leurs contextes socio-économique et environnemental. Cependant, après deux ans, l'instruction de l'APPG n'a toujours pas abouti. Des étapes facultatives et inattendues mais néanmoins nécessaires ont ralenti considérablement les démarches administratives. Cet outil ne permettant pas de mesures conservatoires, son efficacité peut être questionnée dans une région en constante évolution où la pression foncière reste élevée et où les sites géologiques disparaissent rapidement. Cependant, le système juridique français s'est amélioré ces dernières années en encourageant les spécialistes des sciences de la Terre à participer aux instances de consultations locales (CSRPN, CDNPS) afin d'influencer les décisions concernant la protection de ces sites particulièrement menacés.

Mots clés : Arrêté Préfectoral de Protection du Géotope (APPG), patrimoine géologique, protection réglementaire, gisement fossilifère, Lutétien, zone périurbaine

\section{Introduction}

Geological heritage, an integral part of natural heritage, includes all objects (ex situ and in situ) testifying the physical and biological events that have moulded our planet throughout 4.6 billion years (Billet, 2002). A more restrictive definition integrates only the most remarkable and representative objects (Avoine, 2012; De Wever et al., 2015). Geological heritage reflects a vast geodiversity, including a "natural range of geological (rocks, minerals, fossils), geomorphological (land form, processes) and soil features. It includes their assemblages, relationships, properties, interpretations and systems" (Gray, 2004).

The protection of geological heritage in France has greatly evolved since the creation of its first "Reserve": the Forest of Fontainebleau, classed in 1861 by Napoleonian decree (De Wever et al., 2015). Initially protected due to their aesthetic or artistic features, then often associated with biological heritage, geological sites have slowly gained recognition as a true form of natural heritage. The law of 27th of February of 2002 was a turning point in the protection of geological sites because it integrated "geological, mineralogical and paleontological richness" to the notion of natural patrimony. The French state has since devised multiple approaches to help in their conservation: land acquisition approach, contractual approach (the protection and management of the site is delegated to a third party for a limited amount of time as agreed by convention) and the most effective method for long-term conservation, regulatory approach (protection of a site due to the enactment of diverse juridical tools) (Avoine, 2012; De Wever et al., 2014). In the past, regulatory tools such as "Reserves" and "Site Classé" have been successfully used for the protection of geological heritage. However, because their legal proceedings are long and complex with respect to the rapid degradation of geological heritage, on the 28th of December of 2015, the state put in place two strong and seemingly fast-to-enact regulatory tools adapted to the protection of geological objects: (i) the Prefectural Decree concerning the departmental list of geological sites of interest; (ii) the Prefectural Decree of the Protection of the Geotope (APPG). Our study reports one of the first attempts to apply these decrees in the Yvelines department (Île-de-France region) for two threatened sites of immense international value: the Lutetian fossil sites of Grignon and the Ferme de l'Orme. The future of the site of Grignon, situated in the park of the AgroParisTech School, has become uncertain since the state put the property for sale, while the site of the Ferme de l'Orme is regularly pillaged by fossil amateurs, which progressively reduces its heritage value. In our article, we will describe the theory behind the existing regulatory tools - including the APPG - for the protection of geological heritage in France. We will then justify why the sites of Grignon and the Ferme de l'Orme were shortlisted for the APPG amongst many other candidates by discussing their outstanding geological, educational and historical value as well as the imminent threats that they face in the Parisian region. Finally, we will provide advice for a successful enactment of the APPG and an assessment of the advantages and drawbacks of the APPG as a regulatory tool, which we hope will be valuable for the future protection of geological heritage in France.

\section{Progress in the conservation of geological heritage through new regulatory tools in France}

\subsection{Regulatory tools for the conservation of geological heritage before 2015}

Before 2015, the French law contained different regulatory tools within the natural conservation domain that were used for the protection of geological heritage (Fig. 1). For the meaning of the acronyms used in the document please refer to Table 1.

\subsection{1 "Site Classé"}

This tool originates from a seminal environmental law in France, the law of the 21st of April 1906 concerning the 


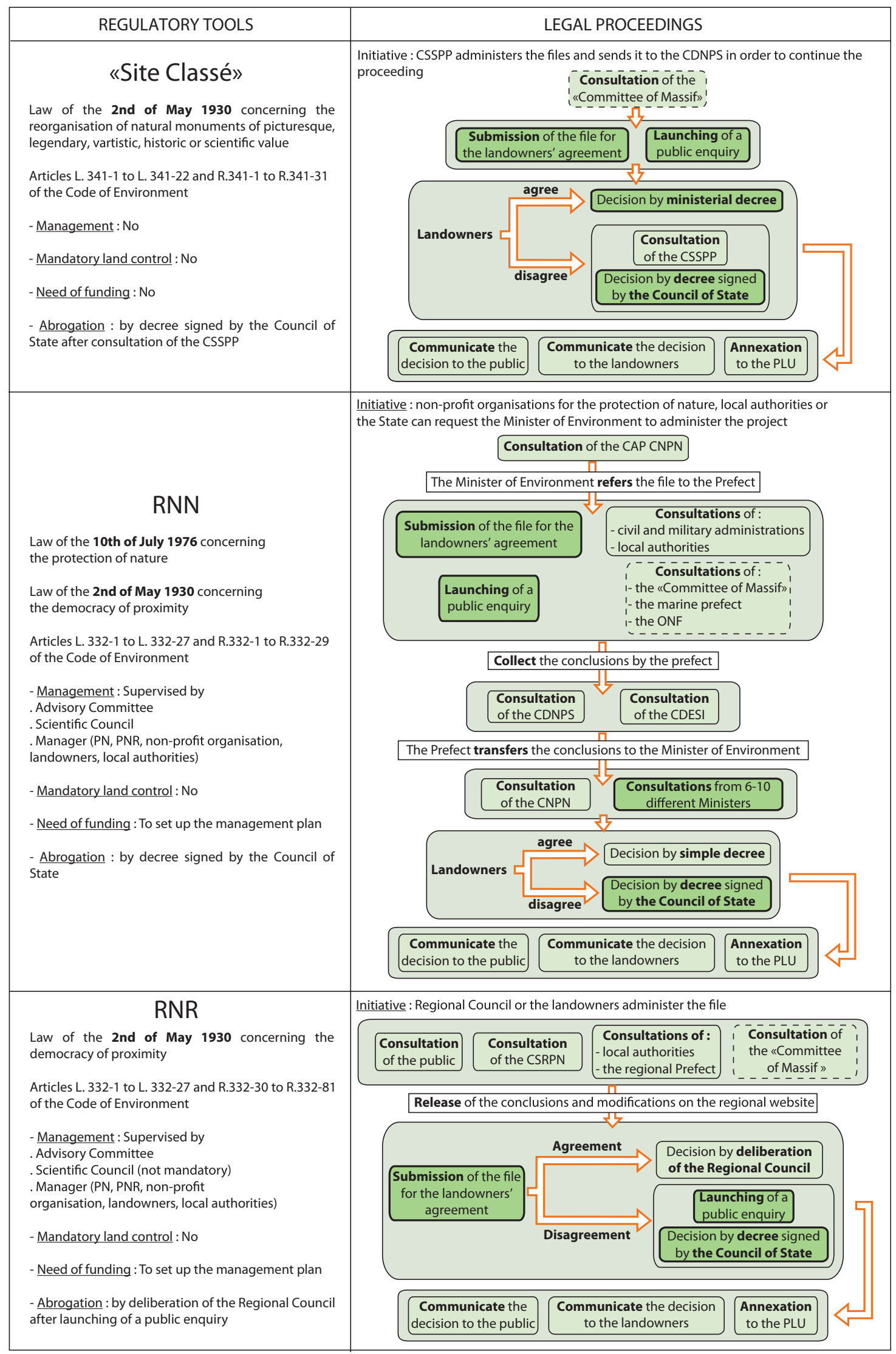

Fig. 1. A summary of the main attributes and legal proceedings of the regulatory tools used for protecting geological heritage in France before 2015. Dark green: relatively long step; dashed contour: step only occurs when the territorial entities are concerned. For the meaning of acronyms see Table 1. 
Table 1. Acronyms used in the document and their meaning.

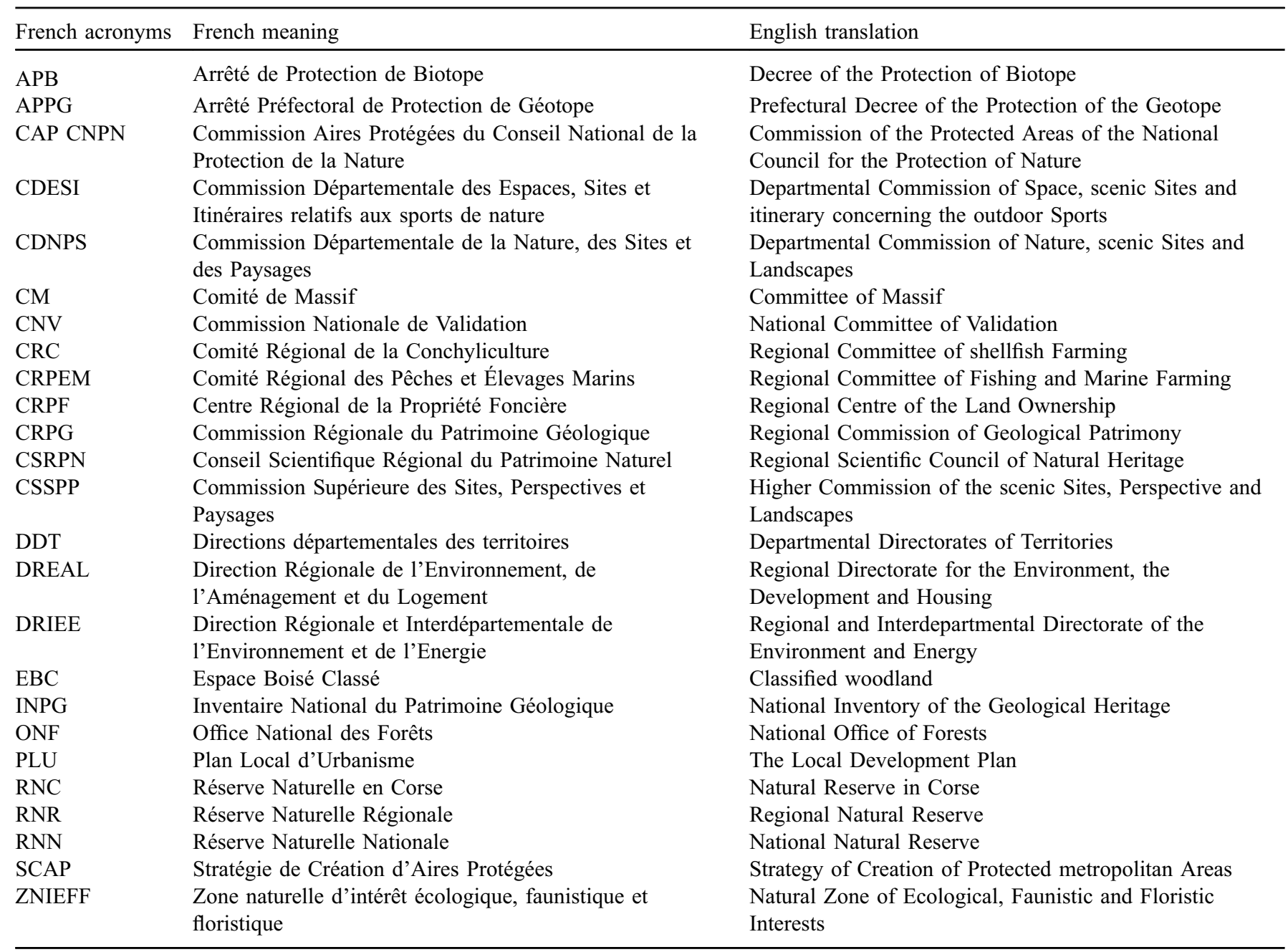

"protection of sites and natural monuments of artistic value", which was later expanded by the law of the 2nd of May 1930 to protect "natural monuments of picturesque, legendary, artistic, historic and/or scientific" value. In 2010, there were almost 2700 "Sites Classés" in France, out of which 74 were classed due to their scientific interest (Jonin and Avoine, 2010).

\subsubsection{Natural Reserves}

The law of the 10th of July 1976 concerning the protection of nature introduced "Natural Reserves" as a classing tool; this law was the first to propose the idea of geological patrimony by allowing to class "mineral and fossil sites" as well as "remarkable geological, geomorphological, and speleological formations". Later on, the law of 27th of February 2002 concerning grassroot democracy officially recognised geological patrimony by including "geological, mineralogical, paleontological richness" within the definition of natural patrimony. This law also conferred more strength to the Natural Reserves by making management plans mandatory and by introducing three types of reserves: National Natural Reserve (RNN), Regional Natural Reserve (RNR) and Natural Reserve in Corse (RNC) (Avoine, 2012; Bétard, 2015). There are currently 343 Natural Reserves in France, out of which 81 present geological interests (Réserves Naturelles de France, 2017).

\subsubsection{National Park}

According to the article L333-1 from the Code of the Environment, this regulatory tool put in place by the law of the 14th April 2006 permits to protect the "fauna, flora, soil, subsoil, atmosphere and water, landscapes and when appropriate, cultural patrimony of special interest" against degradation. Even though geological heritage is not mentioned as such in this law, it is encompassed within the "sub-soil" definition and thus should be protected. However, National Parks are institutions difficult to establish that often protect and manage very large spaces containing a great diversity of landscapes and biotopes. Thus, as noted by Billet (2002), they are not well adapted to the protection of geological heritage. Moreover, amongst the 10 National Parks that exist in France, none is located in the studied area of this article (the Yvelines). For all these reasons, the tool of National Parks will not be further developed here.

Despite having pioneered geological conservation in France, these juridical tools are not completely adapted to 
the vast geodiversity of the country and the rapid evolution of the landscape as a result of anthropic threats. Indeed, a major disadvantage of these tools is their lengthy process of enactment. In a typical procedure to class a natural heritage, the competent administrative authority (e.g., Regional Council) must ask for the agreement of the landowner. If the landowner agrees, the process is expedited and a decree may be signed but if the landowner disagrees, the request must be passed on to the highest authority, the Council of State (Conseil d'État), to sign the decree. Because this requires a long waiting time, it is often preferred to negotiate directly with the landowner. In conjunction with this step, the advice of local stakeholders (e.g., town council, Regional Natural Parks, etc.) is commonly taken into account, which represents an opportunity to integrate the future protected site in the local environmental and socioeconomic context. In the case of "Site Classé" and RNN, the procedure is delayed even further by the launching of a public enquiry (Fig. 1). Moreover, none of these juridical tools are truly specific to geological phenomena/ objects. The law of "Site Classé" is imprecise, as it aims to protect "natural monuments of picturesque, legendary, artistic, historic and/or scientific" value, and thus does not explicitly state whether geological objects should be protected. Geomorphologic objects are often given the status of "Site Classé" simply because they appear as picturesque landscapes (Jonin and Avoine, 2010; Bétard, 2015), however, it is uncertain whether smaller areas like paleontological sites will be included in this law. In contrast, the RNN and RNR do take into account geological objects within their management plans, but also biological ones. The problem arises when these two objects are mutually incompatible. Hypothetically, there could be a case in which a protected species physically degrades a geological object by inhabiting it. As a final financial aspect to consider, the authorities must sometimes allocate money for the management of a reserve (e.g., buying property, refurbishment, creation of educational tools, etc), which we suspect can influence the decision of classing a site.

\subsection{5: Creation of Prefectural Decree concerning the departmental list of geotope and the APPG}

Prior 2015, regulatory tools of the French law did not provide sufficient protection for sites of geological interest and are difficult to implement, which means that geological patrimony of international value was currently at risk of degradation. In light of this juridical void, the law $\mathrm{n}^{\circ} 2010-788$ of the 12th of July 2010 concerning the national engagement for the environment planned the creation of new regulatory tools adapted to the protection of geological sites within their specific environmental and socioeconomic context. To apply this law, the decree ${ }^{\circ}$ 2015-1787 from the 28th of December 2015 - emulated from the existent Decree of the Protection of Biotope (APB) - was thus established to protect geological heritage. This decree describes two prefectural decrees (Note of the 1st of December 2016 concerning the protection of geological sites of interest, [MEEM, 2016]):

(i) the Prefectural Decree determining the departmental list of the geological sites of interest. The sites included in this prefectural decree automatically benefit from protective measures "against the destruction, alteration or degradation of sites of geological interest, such as natural or artificial underground caves, and against the collection, destruction or degradation of fossils, minerals or concretions located in those sites";

(ii) the commonly called Prefectural Decree of the Protection of the Geotope (APPG). It determines specific measures in order to prevent the destruction, alteration or degradation of the sites of the departmental list of the geological sites of interest (described in (i)) (article L. 411-1 to L. 411-2 and article R. 411-17-1 to R. 411-17-2 from the Code of the Environment). This decree is optional if (i) is considered to be sufficient to protect each site.

These decrees are sufficiently flexible in their eligibility criteria to encompass a great variety of geological sites. The chosen sites must present at least one of the three criteria specified in the article R. 411-17-1 from the Code of the Environment:

- international reference;

- scientific, educational or historical interest;

- rarity of the geological object.

In order to constitute the departmental list of sites of geological interest, the competent administrative authority (the Prefect) can rely on two tools of assessment of geological heritage:

(i) list in the Strategy of Creation of Protected metropolitan Areas (SCAP); Following the "Grenelle de l'Environnement", the national SCAP defined by the law ${ }^{\circ} 2009-967$ of the 3rd of August 2009 was created to protect $2 \%$ of natural areas in the French metropolitan territory over the next 10 years. More specifically, it aims for the long-term conservation of species, habitats and geological sites of importance by using tools such as Natural or Biological Reserves, the heart of National Parks, the APB and, of note, the new tool APPG (Egoroff et al., 2011)

(ii) National Inventory of the Geological Heritage (INPG); The law of the 27th of February 2002 concerning grassroot democracy, commanded the establishment of an inventory of "geological, mineralogical and paleotological richness" in France to complete the National Inventory of the Natural Heritage, which started in 1982 with the establishment of the "inventory of fauna and flora" called ZNIEFF. At this time, the CSRPN - a council composed by specialists in all naturalist disciplines - was created in each region in order to evaluate and validate the scientific values of the ZNIEFF (circular $n^{\circ} 91-71$ of the 14 of May 1991). In 2007, when the Ministry of Environment officially launched the INPG, under the scientific responsibility of the Muséum national d'Histoire naturelle (MNHN), a specialised group of the CSRPN, called the CRPG and composed of experts in the different fields of Earth Sciences, was named to monitor the inventory. Even though the law of 2002 specifies that at least one specialist in Earth Sciences - often the president of the CRPG - has to sit in the CSRPN (article L411-1 A of the Code of Environment, De Wever et al., 2014), no law details the composition and role of the CRPG, which results in heterogeneity through the different regions in France.

The methodology of INPG permits to recognise, describe and rank - often through short justifications - geological sites in France according to their heritage interest and their need of 


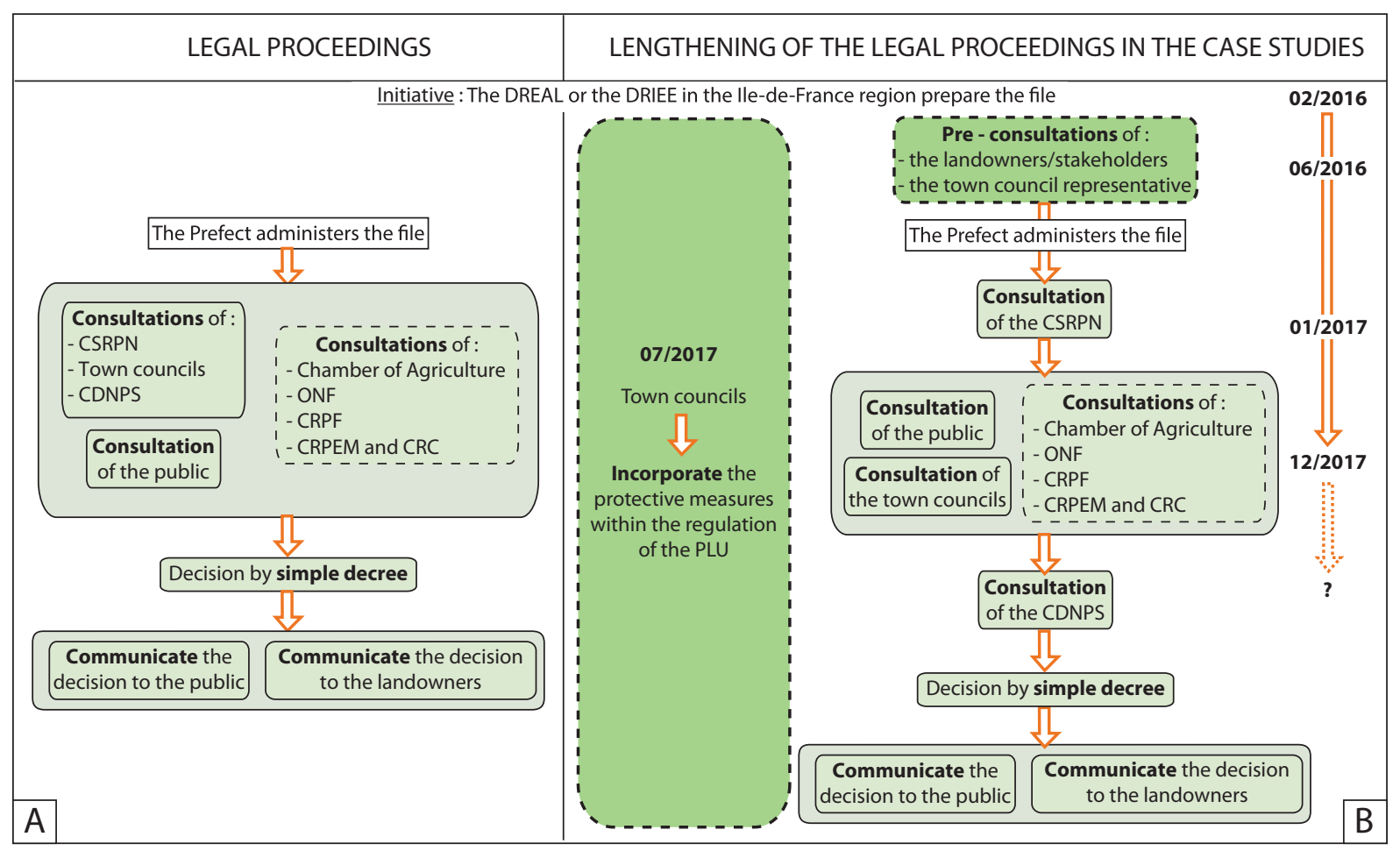

Fig. 2. Comparison between the expected and actual legal proceedings of the two prefectural decrees (the Prefectural Decree of the departmental list of geological sites of interest and the APPG) according to the case study of Grignon and the Ferme de l'Orme. A. The expected legal proceedings are supposed to be fast and easy to enact due to their decentralised nature. $\mathrm{B}$. The actual legal proceedings are considerably lengthened by unforeseen, yet necessary steps. Dark green: relatively long step; dashed contour: step only occurs when the territorial entities are concerned.

protection in order to define appropriate protective measures (De Wever et al., 2014, 2015). Once the CRPG collects the description and assessment of the sites in the regional inventory, these must be first validated by the CSRPN and then by the CNV, which ensures their national coherence.

To put in place the Prefectural Decree determining the departmental list of the geological sites of interest and eventually the APPG, a file must be prepared by the DREAL or the DRIEE in Île-de-France containing (Fig. 2):

(i) the departmental list of the geological sites of interest and their perimeters of action;

(ii) the files that justify the sites chosen in (i): the data of the INPG and/or of the SCAP;

(iii) protective measures against the degradation of each site of interest chosen from the departmental list (APPG) (not mandatory).

The files are then administered by the DREAL or DRIEE in Ille-de-France with support from the DDT. As shown in Figure 2A, the legal proceeding of the file entails simple opinions from the CSRPN, town councils, the formation of "Nature" of the CDNPS and when required, territorial entities such as the Chamber of Agriculture. A public consultation must also be organised before the final decision from the departmental Prefect. These prefectural decisions can be appealed to the Administrative Court by a third party (private individuals, industries, non-profit organisations) within a period of two months after being communicated to the public. Compared to previous juridical tools - RNR, RNR and "Site
Classé" -, the APPG is simpler and quicker to put in place because it does not require a management plan nor a public enquiry and is approved by the departmental Prefect without involving a national procedure (i.e., it is decentralised).

To conclude, the two prefectural decrees for the protection of geological sites of interest appear to be strong juridical tools well adapted to geological objects and with a relatively rapid enactment. Importantly, one of them gives the possibility to describe limiting or prohibitory measures for certain activities that may alter or degrade the geotope. These long awaited tools will be used for the first time in the Yvelines department for the protection of two paleontological sites of international value: the Lutetian sites of Grignon and the Ferme de l'Orme.

\section{Selection of geological sites to be protected by the APPG in the Yvelines department}

\subsection{Geological heritage in the Yvelines department}

The Yvelines department, located on the borders of the Parisian urban area, is one of the eight departments of the Illede-France region. Its geodiversity reflects the history of the sedimentary Paris basin from the Upper Cretaceous until the Quaternary. Here, the lithological section consists of superimposed geological formations alternating between loose facies (sand and clay) and hard facies (sandstone and limestone), which mostly reflect the various cycles of marine transgression and regression during the Cenozoic (Fig. 3A-B). 


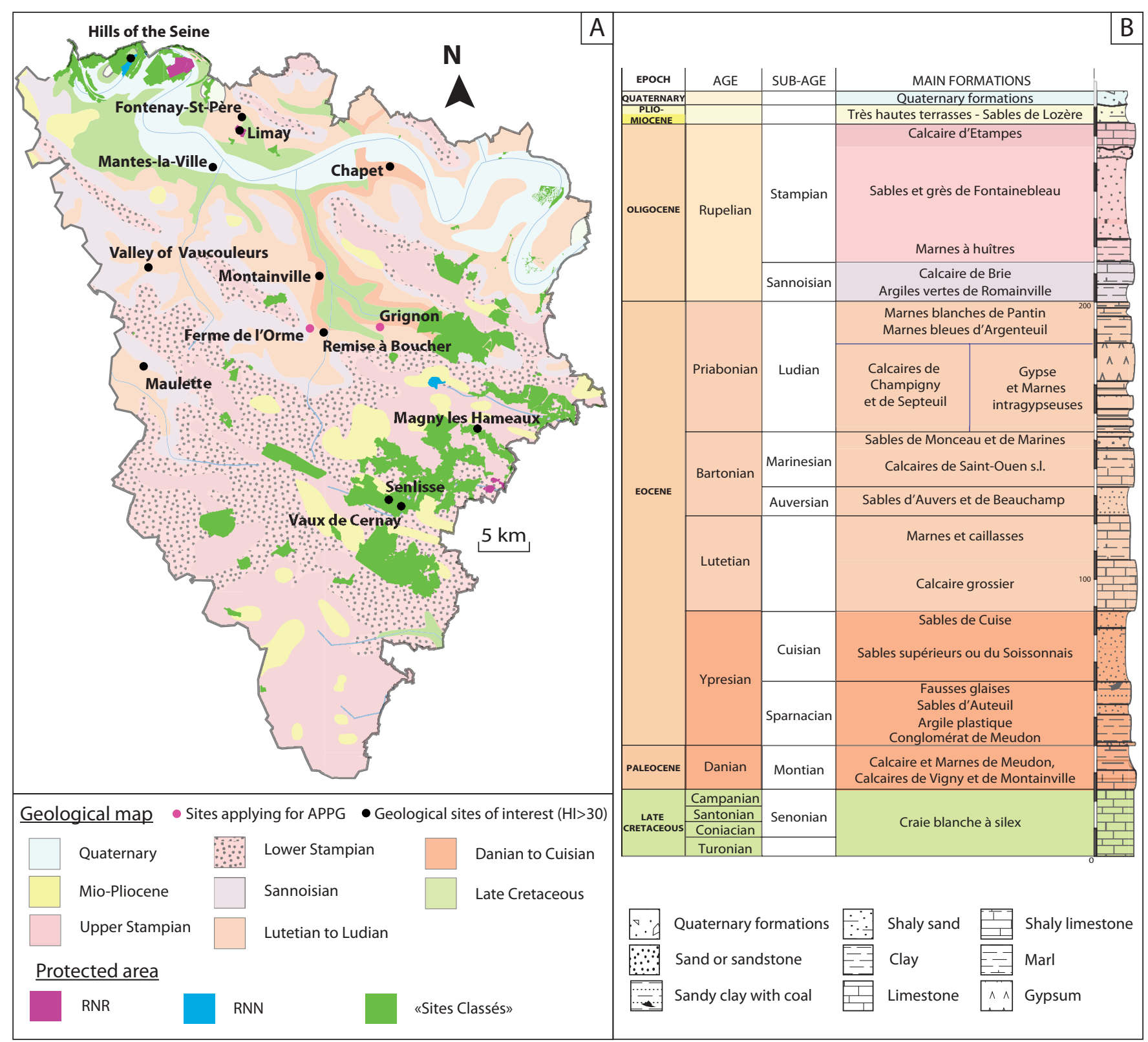

Fig. 3. Geological map (A) and lithostratigraphic section (B) of the main formations in the Yvelines department. The geological sites of national and international interest recognised by the INPG and the different types of protected areas are shown.

In the Plio-Quaternary, fluvial erosion of the loose formations coupled to a tectonic uplift in the North and East of the Île-de-France region brought out four structural platforms, from South to North: structural platforms of the "Calcaire de Beauce, of the "Calcaire de Brie", of the "Calcaire de Saint-Ouen" and of the "Calcaire grossier". During the late Quaternary, the valley sank and continued to erode through periglacial actions. Together, these phenomena finished to sculpt the landscape observed today (Pomerol and Feugueur, 1968). Within the Yvelines department, several sites contain geological treasures that retrace the above geological history. Indeed, some formations contain well-preserved fossils with exceptional biodiversity (Lutetian near the anticline of Beynes) and a few quarries expose complete sedimentary series characteristic of stratigraphic ages (quarries of Limay,
Mantes-la-Ville, Guerville...). Finally, geosites such as Valley of Cernay show astonishing geomorphologic phenomena (Bétard, 2015).

Due to the proximity to Paris, the geological heritage of the Yvelines is exposed to several socio-economic pressures. Large-scale urbanisation projects are taking place in the region, such as the expansion of the underground network referred to as the "Grand Paris project"; as a result, the rural and peri-urban areas are becoming more attractive for residential and industrial settlements as well as other economic activities. In this sector of rapid changes, the recognition and the assessment of the remaining geological sites are necessary in order to preserve geological heritage of interest.

Based on old inventories, the scientific literature (e.g., Fritel, 1910; Abrard, 1925; Alimen, 1936, Morellet and 
Morellet, 1948) and the knowledge of the CRPG members, a preliminary inventory was created within the INPG program that identified 102 geological sites in the $2300 \mathrm{~km}^{2}$ of the Yvelines department. Subsequent field inspections were performed to examine the current state of conservation and the different threats of each site. Unfortunately, the inspections showed that 52 out of the 102 sites have effectively disappeared and must therefore be excluded from the INPG. For instance, $33 \%$ of the 52 sites are no longer accessible due to housing developments, whereas $27 \%$ of them are quarries that have been filled. The latter is quite common in the region given to increasing land pressure and construction waste. Moreover, since a decree in $1977\left(\mathrm{n}^{\circ} 77-1133\right.$ of the 21st of September 1977 , applying the law $n^{\circ} 76-663$ of the 19th of July 1976 concerning the classified installation), active quarries must be restored after finishing extraction, which results in their filling in the majority of cases. A handful of sites have also been spoiled by pollution and uncontrolled excavations (7\%). Although $67 \%$ of the sites have indeed disappeared due to active human intervention, $33 \%$ of them have been lost through natural weathering as well as avoidable re-vegetation of sites of anthropic nature (e.g., quarries).

To fight against these threats and to maintain the integrity of the main natural sites, a few regulatory tools have been put in place in the last decades (Fig. 3A). Since the middle of the 70 's, several natural sites presenting remarkable geomorphological heritage have been protected by the juridical tool "Site classé" in virtue of their picturesque, artistic, historic and/or scientific characteristics (Bétard, 2015). This is why the sandstone flat hills and block fields in the Valley of Mérantaise (1976), the Valley of Cernay (1980) and the "Les Rochers d'Angennes" (1986), as well as the famous confluence of the Seine and the Epte (1985) facing Port-Villez, the chalky hills of La Roche-Guyon and the forest of Moisson (1990) "cannot be destroyed or modified" by human activities. Near the RocheGuyon, the hills of the Seine were further classed as a RNN in 2009 to protect exceptional biological habitats. Although this measure was conceived only in the interest of the local biodiversity, the management plan of the reserve mentioned the importance of the subsoil and recognised various geomorphological and geological objects. To date, the only protected area in the Yvelines department where geoheritage is openly recognised is the RNR of Limay (created in 2009). This reserve preserves one of the most complete geological sections in the Île-de-France region. The different stratigraphic levels from the Campanian to the Upper Lutetian are exposed in different parts of the protected area and provide remarkable geological objects such as numerous fossils (e.g., fish teeth from Upper Ypresian and imprints of molluscs from Lutetian) and extensive sedimentological figures (oblique stratifications testifying of the direction of the paleocurrent).

In summary, laws of conservation in the Yvelines department have mainly focused on protecting biological and geomorphological heritages, but have generally neglected other geological interests (e.g., paleontological, sedimentological, stratigraphical), which are not as well known to the public. We hypothesise that the two prefectural decrees for the protection of geological sites of interest, juridical tools specific to the geology and which should be implemented fast, will help the authorities protect the main sites of geological heritage of the department.

\subsection{The National Inventory of the Geological Heritage: help to designate candidates}

The INPG assigns grades to sites (from 0 to 3 ) according to their heritage interest (HI) (including main and secondary geological interests, educational interest, geological history interest, rarity of site and preservation state) and their need of protection (NP) (including heritage interest, natural and anthropic vulnerability and effective protection); it is thus a useful tool for highlighting the main geological sites in danger of a particular region (De Wever et al., 2014, 2015). As shown in Figure 3A and Table 2, 14 sites in the Yvelines department possess at least a national heritage interest $(\mathrm{HI}>30)$. These sites are not only heterogeneous in terms of their typology (quarry, outcrop and geosite) but also in terms of their stratigraphic age and patrimonial interest (stratigraphy, palaeontology, geomorphology and sedimentology). Amongst them, the top three recognised sites (Tab. 2) are Grignon, with a grade of 46, Montainville with a grade of 41 and the Ferme de l'Orme, with a grade of 39. They were recognised mainly for their paleontological and stratigraphic interests of international value.

\subsection{Justification for the final selection of the sites of Grignon and the Ferme de l'Orme}

\subsubsection{Urgency of conservation}

The SCAP (Strategy of Creation of Protected Areas) whose goal is to protect $2 \%$ of the French territory by 2019 , did an initial assessment of the geological heritage (Egoroff et al., 2011) and recognised only two remarkable sites in the Yvelines department: the Lutetian fossil sites of Grignon and the Ferme de l'Orme. However, before 2016, no legal procedures were established to protect them because they were assumed to be safe. Indeed, the first one, located in the Park of AgroParisTech School, has been under the jurisdiction of the French state for two centuries; while a small portion of the second one - an historical quarry - was bequeathed to the MNHN by its last owner Paul Lemoine in order to give it "land control" protection (Figs. 3 and $4 \mathrm{~B}$ [site ${ }^{\circ} 8$ ]). At the end of 2015, the AgroParisTech School announced its plan to move to the plateau of Saclay by 2020 and the Ministry of Agriculture put the domain to sale, making the future of the site uncertain. The site of the Ferme de l'Orme does not benefit from any physical protection nor surveillance, and consequently, it is visited regularly by numerous fossil amateurs. The uncontrolled excavations have made the quarry faces very dangerous and have depleted many varieties of fossils; thus exhausting the limited geological potential in the parcel protected by "land control". Recognising this, at the beginning of 2016, it seemed urgent to follow the SCAP directives to protect these paleontological jewels, which is why these sites and their geological potential were selected for the Prefectural Decree of the departmental list of geotope and the APPG.

The site of the Danian limestone of Montainville was also envisaged as a candidate for the APPG due to its second position in the departmental list of the INPG (Fig. 3 and Tab. 2) $(\mathrm{IH}=41)$. However, it was discarded because the threats were considered minor $(\mathrm{NP}=9)$. The Local Development Plan (PLU) of Montainville only shows areas unfavourable to constructionnatural zone of classified woodland (EBC), natural zone susceptible to erosion and agricultural zone. The position of the quarry and the presence of abundant vegetation also make it 
E. Auberger et al.: BSGF 2018, 189, 3

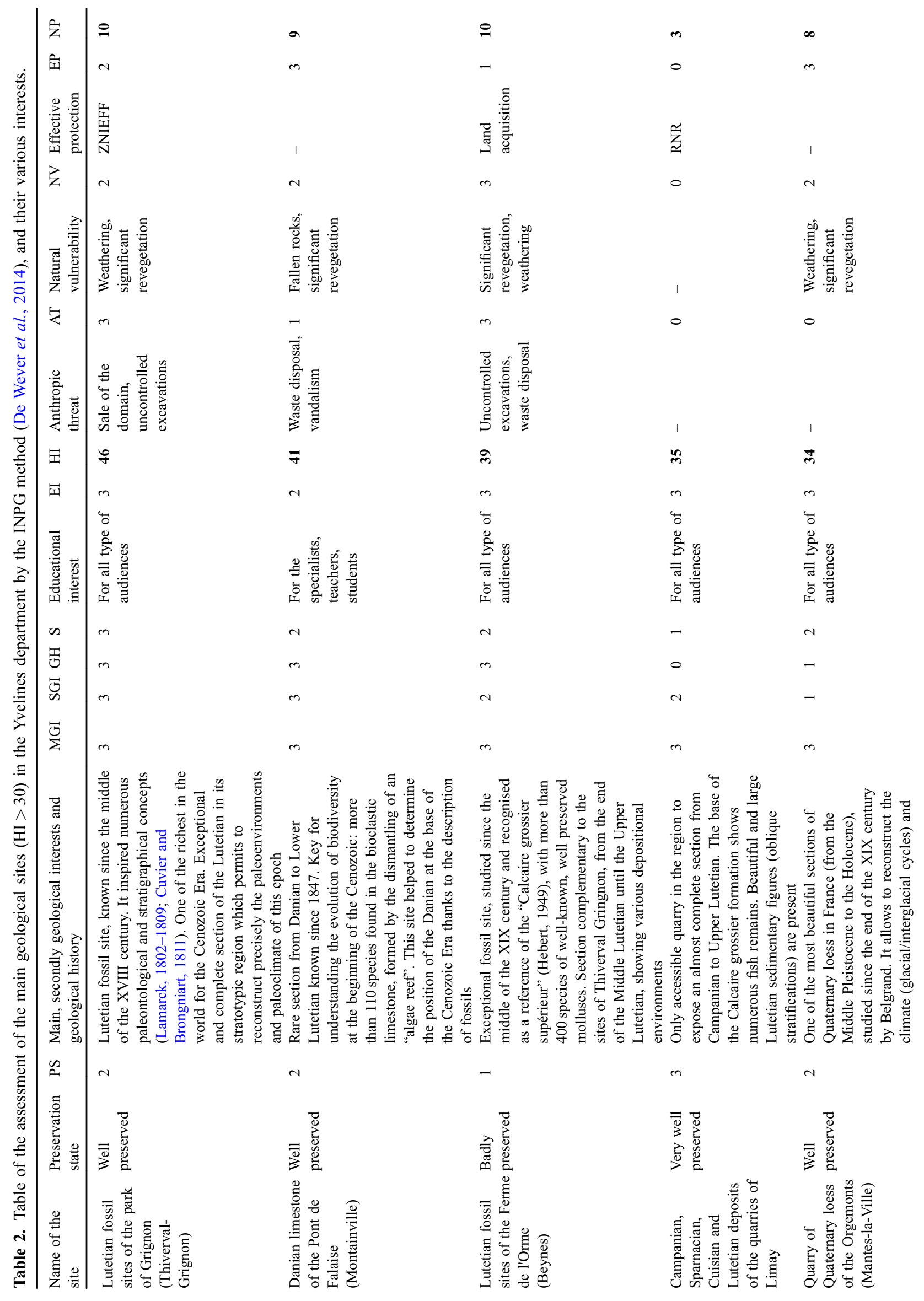




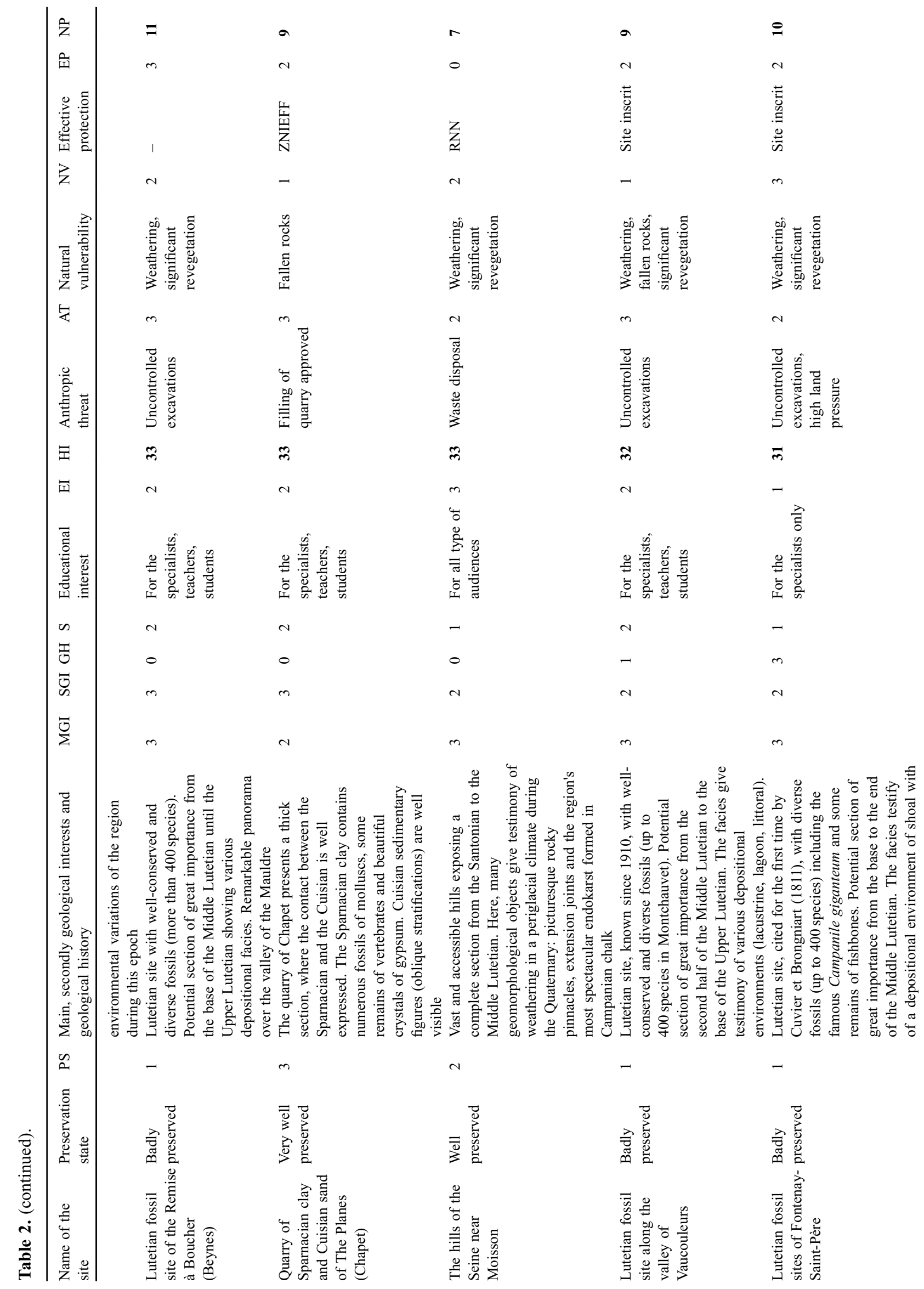


E. Auberger et al:: BSGF 2018, 189, 3

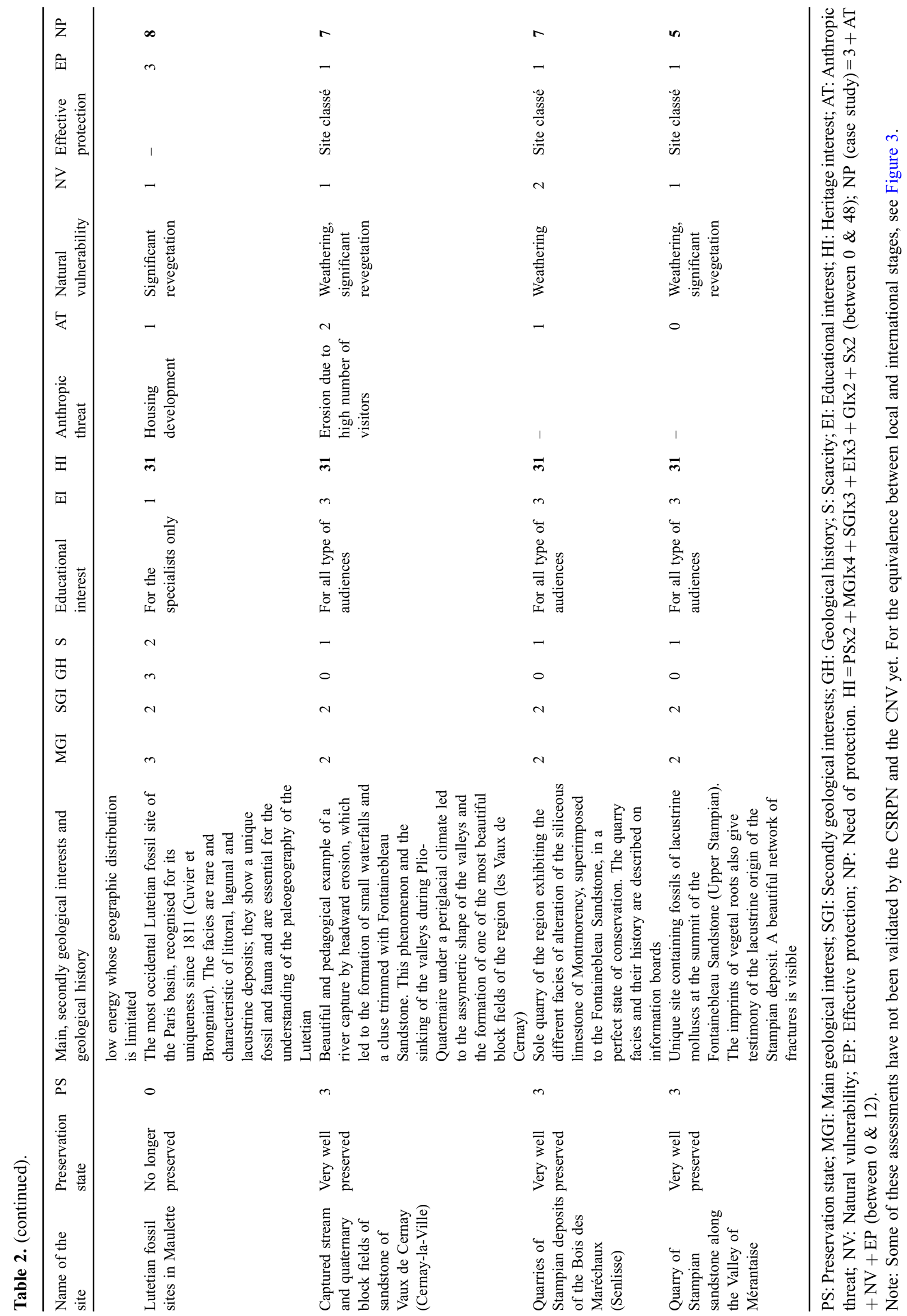


unlikely to be degraded by illegal littering. Further to this, the perimeter of the geological site contains several cadastral parcels whose owners remain unknown, which would have slowed down the preparation of an application file for the APPG. It is important to highlight that this department list of the géotope, once accepted by the Prefectural Decree, is not exhaustive, which means that sites like Montainville and the Remise à Boucher in Beynes - whose urgency of conservation is not as high - could be included in a subsequent stage of application.

\subsubsection{Fulfilment of the eligibility criteria}

The domain of Grignon and the site of the Ferme de l'Orme are located at 30 and $36 \mathrm{~km}$ West of Paris (Fig. 3A), respectively. Grignon contains six areas of geological and historical interest, out of which five have been rediscovered recently (Riding hall, Old galleries, The Maugère, The Parc, The Côte-aux-Buis, Fig. 4A), and whose study allows to reconstruct a section from the Campanian to the Upper
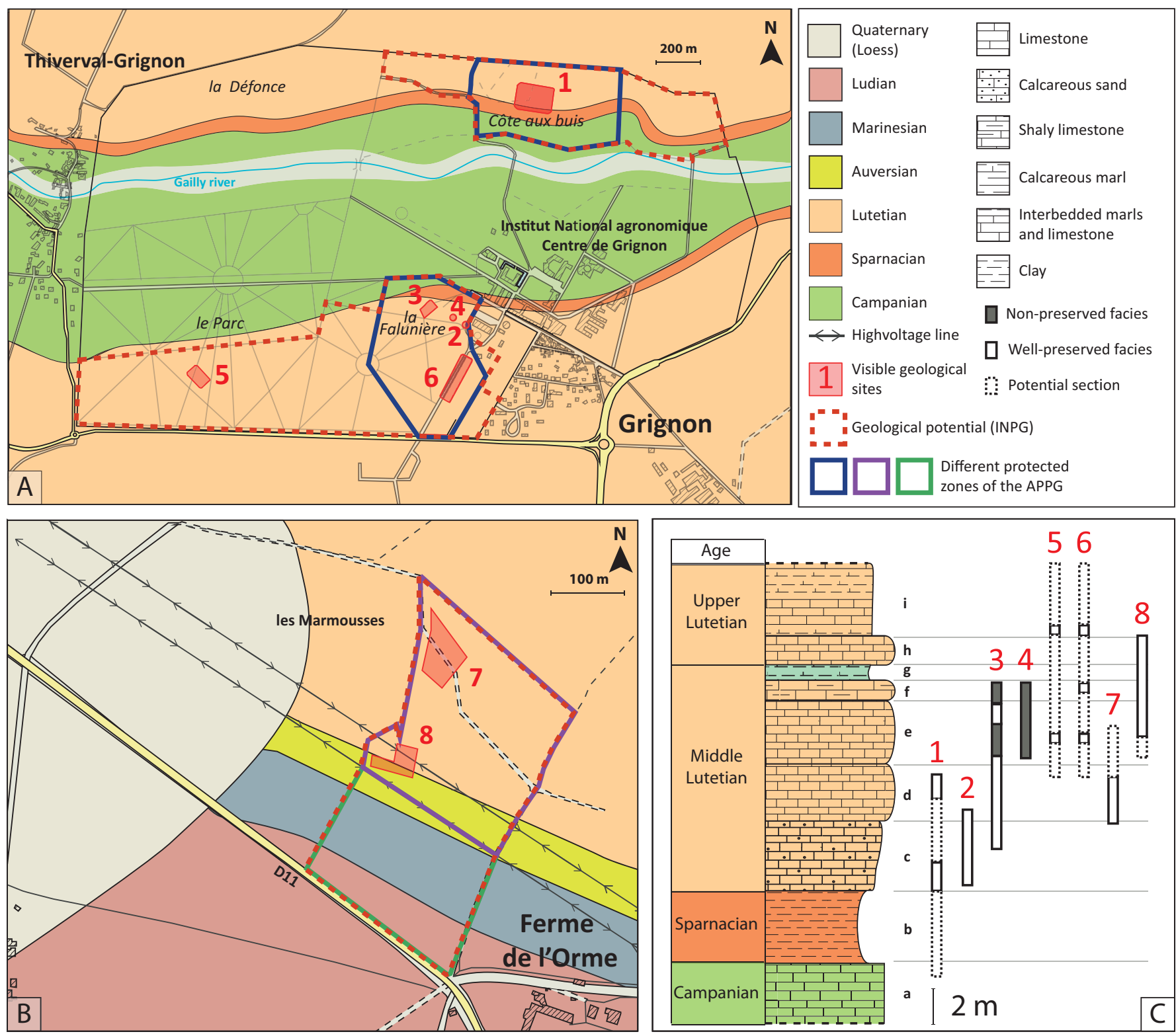

Fig. 4. The location and distribution of visible geological sites of Grignon and the Ferme de l'Orme on their geological map and correlated section. A. In Grignon, the protected zone of the APPG is highly reduced compared to the geological potential defined by the INPG (map adapted from Merle et al., 2016). B. In the Ferme de l'Orme, two types of areas with different protective measures were defined in order to facilitate the negotiation of the APPG. In the purple area it is forbidden to excavate beyond $1 \mathrm{~m}$, whereas in the green area it is authorised up to $4 \mathrm{~m}$. All other regulatory measures apply to both areas. C. The well-preserved sections outcropping in the sites of the Ferme de l'Orme and Grignon complement each other, which highlights their stratigraphic interest. A-1) The Côte-aux-Buis, 2) Old galleries, 3) The Falunière, 4) The Riding hall, 5) The Parc, 6) The Maugère, B-7) Edge of the forest, 8) The quarry. C-a) The Craie à Silex, b) Argiles plastiques, c) Bed with Campanile giganteum, d) Bed with Milioles and Orbitolites, e) Bed with Avicularium lithocardium and some plants, f) Bed with Potamides and Batillaria, g) Green marls with Lymnea and Staliola, equivalent of the "Banc Vert" of Paris, h) Bed with Sigmesalia, i) Marnes et caillasses. 
Lutetian (Fig. 4C). The most famous area called the "Falunière", is an ancient quarry, nowadays physically protected and well maintained. In the site of the Ferme de l'Orme, the geological heritage outcrops in an old, vegetated and polluted quarry, as well as in its surrounding fields (Fig. 4B). The study of the site permits to establish a section from the end of the Middle Lutetian until the Upper Lutetian (Fig. 4C). The sites of Grignon and the Ferme de l'Orme are complementary in their geological interests and respect all the eligibility criteria required to apply for the APPG.

\subsubsection{They show various scientific, educational and historical interests}

\subsection{Stratigraphic interest of international value}

The different outcrops located in Grignon and the Ferme de l'Orme allow to reconstruct the most complete and preserved section of Lutetian in its stratotypic area (Fig. 4). Indeed, apart from the end of the Middle Lutetian to the Upper Lutetian, multiple levels in Grignon have not been affected by diagenetic alteration (dissolution and recrystallisation phenomena), and consequently, contain numerous undamaged marine fossils (Sanders et al., 2015). The visible outcrops in the Ferme de l'Orme complete the remaining part of the well preserved Lutetian section and permit to study, in perfect conditions, a rare lacustrine level equivalent of the "Banc vert" of Paris. The latter is very important in sequential stratigraphy because it indicates the transition between the Middle and the Upper Lutetian. The different facies contain abundant index fossils, such as various foraminifera (190 foraminifera species described in Grignon (Le Calvez, 1970)), which allow to correlate each bed to the sections of reference in order to date them precisely. It should be kept in mind that the Lutetian Stage is recognised as a reference on the International Chronostratigraphic Chart for all the geologists in the world. France has therefore the responsibility towards the scientific community to conserve the sections of Grignon and the Ferme de l'Orme due to their international value.

\subsection{Paleontological interest}

The Lutetian of the Paris bassin constitutes a hotspot of paleobiodiversity, whose central fossil site resides in Grignon. Collections dating back to the middle of the 19th century, have helped to recognise Grignon as the richest Lutetian fossil site in the world in terms of paleobiodiversity, surpassing considerably the second richest region, the plain of the Golf Coast in United States of America (Merle, 2008). With more than 800 species in Grignon (less than 400 species in the Golf Coast), molluscs are the best represented taxon (where more than 500 are gastropods). The microfauna, particularly the foraminifera, are extremely varied too (Le Calvez and Le Renard, 1980). Even though the inventory is highly thorough, new species may still be found. In 2016, statoliths of Sepia (cuttlefish) and Loligo (squid) found in the fossil site allowed to identify three new species (Neige et al., 2016). These are the oldest fossils of cuttlefish and squid found in the world. Grignon contains an impressive total of more than 1200 species in over less than a hectare, and thus represents an essential fossil site for understanding the evolution of the biodiversity during the Cenozoic. The site of the Ferme de l'Orme has also been referred to as one of the richest in the Paris basin (Fritel,
1910). It contains close to 400 species of molluscs and some species of calcareous algae (Abrard, 1925; Blondeau, 1965). In contrast to the big molluscs of the Middle Lutetian found in the Falunière of Grignon (e.g., level of Campanile giganteum), here we find unique, small specimens coming essentially from a level called limestone of Orbitolites complanatus (end of Middle Lutetian). These exceptional paleobiodiversities are accessible today because the non-lithified limestones of Grignon and the Ferme de l'Orme have barely been altered by diagenesis. Such a rare context allowed the preservation of pigments on shells aged 45 million years. It is possible to reveal the coloration patterns of the shells by exposing them to UV light, a technique developed by Caze (2010), which incorporates new data in the study of inter and intraspecies variability to understand their evolution. In summary, Grignon and the Ferme de l'Orme are considered as fossil sites of exceptional conservation in the world, referred to as "Konservat Lägerstatte" (Merle et al., 2016).

\subsection{Paleoenvironnemental interest}

The well-preserved facies in Grignon and the Ferme de l'Orme permit to investigate the environmental factors that led to the appearance and disappearance of this Lutetian "hotspot" of paleobiodiversity. For example, by performing highresolution geochemical analyses of stable isotopes of oxygen $\left(\mathrm{O}^{18}\right)$ in shells of molluscs from Grignon, it was possible to reconstruct the evolution of sea-surface palaeotemperatures during the Lutetian. Contrary to old theories that had proposed a tropical climate in the Paris basin during this period - based on the high density and type of fossils (Abrard, 1925) - a mild cooling seems to have happened: from $30^{\circ} \mathrm{C}$ in the Ypresian to $22^{\circ} \mathrm{C}$ at the end of Middle Lutetian (Huyghe et al., 2012). Grignon and the Ferme de l'Orme may also serve as a model for understanding the dynamics of other hotspots around the world, which is of particular importance in the current context of the sixth biological crisis. To study the relationship between biodiversity-stratigraphy-sedimentology-climate at high resolution, several research programmes comprising multidisciplinary French and international teams are currently under way using in situ material from Grignon and the Ferme de l'Orme (Merle et al., 2016).

\subsection{Educational interest}

The sites of Grignon and the Ferme de l'Orme represent an excellent educational tool for the diffusion of Earth Sciences (Merle et al., 2016). Thanks to the visible and simple sections, as well as the Lutetian levels full of well-preserved fossils, numerous disciplines of geology can be taught to a heterogeneous public. The visitors can understand and even elaborate on the simple concepts of stratigraphy and paleontology, and indirectly, on other disciples such as paleogeography, paleoecology and biological systematics. Since 2007, the students registered in Master 1, speciality "Systematics, Evolution, Paleontology" of the MNHN participate in a field trip to Grignon and the Ferme de l'Orme to measure indices of paleobiodiversity and to study the ecology of past organisms. Students training to be teachers of Biology and Earth Sciences from the University Pierre et Marie Curie also visit these sites, where they receive multidisciplinary courses combining geology, biology and 
history of science, in accordance to the growing demand for transversal teachings in secondary schools. Visiting students have agreed that Grignon's Faluniere helps to restore the negative image that geology has for the vast majority of teachers of Biology and Earth Sciences. Finally, the general public can also visit the vast fossil collection of the "Club Geologique d'Île-de-France de Grignon", located at the entrance of the park of Grignon, during events like "heritage day".

\subsection{Historical interest}

The history of the fossil site of Grignon is intimately linked to the emergence of Geology as a modern field of study, particularly in the disciplines of palaeontology and stratigraphy (Merle et al., 2016). As early as 1751, Dezallier d'Argenville first discussed "the abundance of big white fossil shells in Grignon: "In praedio Grignon prope (d) Versalias extant fodinae arenariae, ex quibus oritur concharum fossilium magnus numerus albido colore exiguâque formâ. Apparent praecipuè Murices, Buccina, Turbines, Globosae, Pectines, Chamae, Cocleae depressae vulgò l'Eperon, Tellinae, Harpa nobilis, Porcellaneae, Mitella Sinensis vulgò Cabochon, conchae rariores seu, Anomiae, \& Buccardia". Later on, the founding father of binomial nomenclature, Carl Linnaeus, described in detail various shells of the Lutetian Paris basin. Amongst them, the bivalve Cardium lithocardium Linnaeus 1771, is found almost exclusively in the surroundings of Grignon. J.B. Lamarck immortalised the site 30 years later with his work "Mémoire sur les coquilles fossiles des environs de Paris [...]" (Lamarck, 1802-1809) by highlighting the diversity of fossil species. The work of Lamarck was continued by other renowned malacologues like Deshayes and Milne Edwards (Deshayes et al., 1835), who relied on specimens from Grignon but also for the first time from the Ferme de l'Orme. Contemporaneous, eminent authors such as Cuvier and Brongniart (1811) provided one of the first synthetic sections of the Parisian region - from Paris to Grignon - in their "Essai sur la géographie minéralogique des environs de Paris", while in 1849 , E. Hébert cited Grignon and the Ferme de l'Orme as references of the "Calcaire grossier supérieur". Indeed, throughout the end of the 19th century, Grignon was cited by both geologists and palaeontologists. In 1900, extensive refurbishment works led by $\mathrm{S}$. Meunier were carried out at Grignon for the occasion of the International Congress of Geology. Fritel (1910), the author of the first geological guide of the Parisian region, further recognised Grignon and the Ferme de l'Orme as sites of major geological interest. The historical value of Grignon and the Ferme de l'Orme thus resides in their pioneering role for the development of scientific ideas in the field of Geology.

\subsubsection{They are an international reference}

The international community has had a long-standing interest in Grignon and the Ferme de l'Orme due to their paleontological and stratigraphic values (Merle et al., 2016). This is reflected in the number of publications concerning these sites: more than 110 references for Grignon - the oldest dating to 1753 -and 80 for the Ferme de l'Orme over a period of two and a half centuries, many of which have become seminal references in the scientific literature. Although the body of work is understandably dominated by French authors, scientists from USA, Sweden, Italy, Austria, Switzerland and Czech Republic have also studied these two sites, and many recent works have been published in journals of international audience. Having already hosted scientists from the International Congress of Geology in 1900, Grignon will be visited in 2018 for the occasion of the 5th International Paleontological Congress in Paris, where more than 1200 scientists from all over the world will gather.

\subsubsection{They include rare geological objects}

The Lutetian of the Paris basin is renowned for its exceptional paleobiodiversity, in particular the well-preserved shells of molluscs. However, the sites with high density of shells, still numerous in the 1950s, have diminished dramatically in the past few years due to housing developments and uncontrolled excavations (Merle et al., 2016). Sites such as Villiers Saint-Frédéric (78) and Chaussy (95), which were known as some of the richest, have either disappeared or are no longer accessible. Today, the only protected Lutetian sites in the Parisian region (Quarries of Limay, Saillancourt and the Roche-Guyon) display interesting geological sections but are poor in macrofossils due to their paleogeographical context and/or their diagenetic alteration (dissolution phenomena). Accordingly, it is essential to protect the increasingly rare paleobiodiversity of Grignon and the Ferme de l'Orme.

Finally, both Grignon and the Ferme de l'Orme respect all three criteria of eligibility for the APPG. It should be highlighted that all these characteristics were reported in the data of the INPG, and the latter were validated by the CSRPN and the CNV.

\section{Feedback on the application of the APPG}

The creation of the APPG was received with enthusiasm by the geological community in France due to its presumed ease of enactment and specificity towards the protection of geological heritage. The sites of Grignon and the Ferme de l'Orme, which aim to be the first areas protected by the APPG, represent excellent case studies to understand the practical difficulties of using these tools.

\subsection{Lengthening of the legal proceedings}

\subsubsection{Determining the protective measures and perimeters}

The note of 1 st December 2016 concerning the protection of geological sites of interest (MEEM, 2016), states that the protective measures must not interfere with local economic activities, assuming that the latter do not pose a direct threat to the geological heritage. It can thus be inferred that the prefect, who has the final say on the approval of the APPG, may be reluctant to sign the decree when there are different conflicts of interest. In order to reach an agreement regarding the perimeter and protective measures of the future classed area, we found it necessary to organise a pre-consultation with the landowners and the different stakeholders (e.g., ONF), even though the 
APPG does not require it (unlike the RNN and the tool "Site Classé") (Figs. 1 and 2). The delineation of the perimeter of action requires careful thought: the chosen area must encompass as much geodiversity as possible while interfering the least with the local economic activities. For example, even though the geological potential of the site of Grignon spans about 87 hectares - as determined by the INPG - , this area was considerably reduced to 37 hectares so as to retain only nonredundant stratigraphic sectors such as the Riding hall, Old galleries, The Maugère, The Parc, The Côte-aux-Buis and notably, the Falunière (Fig. 4A-C).

The Prefectural Decree determining the departmental list of the geological sites of interest is meant to provide legal protection to the sites within the list, however, its measures of protection remain general and are not adapted to the local context. As such, it is strongly advised to put in place the Prefectural Decree determining specific measures preventing the degradation of the sites of the Geotope (APPG), which details prohibited actions adapted to existing and potential threats as well as authorised ones in order to strike a consensus between the protection of the heritage and the interests of the landowners and the stakeholders. At present, the biggest threats for Grignon and the Ferme de l'Orme are urbanisation, construction work or renovations (which may modify the subsoil) and uncontrolled excavations. The regulations of the PLU are helpful in determining authorised activities that may become potential threats. For example, in the natural, forest and agricultural zones of both Grignon and the Ferme de l'Orme, some sectors may be exceptionally designated for construction, or for the establishment of traveller's camps and removable residences (L.151-13, Code of Urbanism). As such, the management of activities like these must be detailed and discussed in the measures of protection defined in the APPG.

It is thus forbidden:

- to collect fossils and sediments;

- to excavate the soil beyond $1 \mathrm{~m}$;

- to camp (including traveller's caravans) and to start bonfires;

- to drive motorised vehicles $(4 \times 4$ cars, motorcycles $)$ and ride mountain bikes;

- to litter or to deposit any kind of waste;

- to create new roads or trails;

- to raise, level, fill or waterproof the ground with external materials.

General exceptions and authorisations:

- the prefect may exceptionally authorize the collection of fossils, minerals and/or concretions for scientific and educational purposes according to the article R411-17-2 of the Code of the Environment and following advice from a specialist (a geologist or a palaeontologist) from the MNHN. Archaeological excavations and water drillings superior to $1 \mathrm{~m}$ may also be given permission;

- landowners, entitled personnel and public servants are permitted to circulate outside of trails in case of necessity;

- any construction or maintenance work is allowed in the event of managerial and educational projects or for the welcoming of the general public (with the landowner's agreement), unless it puts under threat the integrity and the accessibility of the geological sections;

- forestry and agriculture are still authorised in their respective PLU zones.
Particular authorisations (in the case of Grignon):

- the school of AgroParisTech and the French National Institute of Research for Agriculture (INRA) (the main stakeholders) are allowed to excavate the soil beyond $1 \mathrm{~m}$ for research purposes (experimental agriculture, study of soils); - any equitation-related activities are authorised within their already designated zone.

The perimeter of the APPG may be subdivided into areas with different levels of protective measures according to the distribution of the geological objects, which helps in the negotiation process of the APPG. For example, in the case of the Ferme de l'Orme, the concession of a zone (Fig. 4B, green zone) with more lenient protective measures conciliated the landowners. In this zone, in addition to the general authorisations detailed above, the construction of agricultural infrastructure is permitted (as determined by the regulations of urbanism), as long as soil excavations do not exceed $4 \mathrm{~m}$.

\subsubsection{Organising consultations in a specific order}

In order to put together a solid and persuasive application file for the APPG, the DRIEE decided to organise the consultations in a specific order (Fig. 2B):

- 1st consultation: CSRPN. The validation of the geological heritage of interest by scientific experts in the different domains of Life and Earth Sciences gives credibility to the application since the beginning;

- 2nd consultation: public and stakeholders. This aids in showing that all conflicts of interest between the parties involved have been addressed;

- 3rd consultation: formation of the "nature" of the CDNPS. The prefect commonly relies on the opinion of this commission for juridical procedures concerning the protection of nature, as it is composed of numerous and diverse actors of the territory divided in 4 colleges of local actors: 1) representatives of the state; 2) representatives of elected members; 3) people qualified in the domain of nature, in its protection, in agriculture and silviculture; 4) people whose competences can intervene with or be related to the protection of nature. This consultation is done last in order to present the most robust application file.

\subsubsection{Dealing with an unforeseen step:}

A juridical flaw of the APPG is that it is not considered a "public utility easement" (servitude d'utilité publique), which means that the town council does not have the obligation to report the protected perimeter on urbanism documents such as the PLU and may render the APPG invalid in a contentious case. To avoid this scenario, in parallel to the legal proceedings, the town council should commit to register the protective goals of the APPG within the regulation of the PLU. Ideally, the modification of the PLU, which can be a long process, should happen before the signature of the APPG.

Although in paper the legal proceedings of the APPG were meant to be faster and simpler compared to previous juridical tools, the reality is otherwise (Fig. 2): after almost two years since the beginning of the legal proceedings of the APPG for Grignon and the Ferme de l'Orme, the DRIEE has only just 
submitted the file for the consultation by the town council, the chamber of agricultures and the regional centre of land property. This was due to the addition of a non-mandatory yet advisable pre-step in the legal proceedings, to numerous corrections made to the chosen perimeter of action and the protective measures (following consultations by landowners, the CSRPN, etc.), as well as the unforeseen need to reconcile the APPG with the PLU.

\subsection{Disadvantages of the APPG}

The unexpectedly lengthy procedure of enactment of the APPG has put in question its applicability in the fast-evolving socioeconomic context of the Yvelines, where $60 \%$ of sites have disappeared in the recent years due to housing developments and filling of quarries. On this respect, the reserves and the "Site Classé" tools are more advantageous than the APPG in that they forbid any modification of the proposed site-to-be during their legal procedure, thus allowing the preventive protection of sites in case of unforeseen urban expansion (Articles L332-6 and L341-7).

The APPG are also unsuitable for the protection of heritage in quarry sites because the decrees can only be enacted after a quarry has been restored (often by filling) - as envisaged in the quarry project plan-, when geological objects are often inaccessible or lost (Note of 1 st of December 2016 concerning the protection of geological sites of interest, [MEEM, 2016]).

\subsection{How to increase the recognition of geological patrimony to facilitate the enactment of the APPG}

It is evident that the enactment of an APPG depends on: i) the patrimonial value of the geological site; ii) the understanding of the issues affecting the geological site visà-vis their local context (e.g., economical context) by consultative bodies. The scientific argument of the INPG, gathered by the CRPG, is thus essential for an APPG to be approved. Unfortunately, the description of the geological sites and the justification of the assigned grades in the INPG are rarely sufficiently detailed. Moreover, the data may be heterogeneous and even incomplete depending on the expertise of the CRPG members in each region. Given that the inventory programme in Île-de-France began in 2015, which coincided with the creation of the APPG, the sites of Grignon and the Ferme de l'Orme were very well described, as in the previous part of this article, in order to help with an application for this decree. In addition, the DRIEE put together a file to clearly and pedagogically expose the patrimonial issues of these sites.

Historically, the CSRPN was created to evaluate the patrimonial value of the ZNIEFF, while the specialised formation of "nature" of the CDNPS advises in the juridical proceedings of the RNR, the APB and Natura 2000. Given that these tools did not place a major emphasis on geological patrimony, it is not surprising that Earth Sciences specialists have not occupied many seats in these consultative instances in the past. This changed when the law of $27 \mathrm{th}$ of February of 2002 concerning grassroot democracy officially ordered that at least one Earth Sciences specialist sits in the CSRPN. This member is often the president of the CRPG. Despite the
CSRPN having acquired geological competences in the recent years, the CRPG remains the most apt commission to advice on the regional sites of geological interest. If they were recognised by the law, the CRPG could replace or complement the CSRPN in missions concerning the protection of geological sites. Professional or amateur geologists can also apply to be part of two colleges of the CDPNS: 1) people qualified in the domain of nature, in its protection, in agriculture and silviculture; 2) people whose competences can intervene with or be related to the protection of nature. Their involvement would help to understand the interests of geological sites and to sensitise the other members of these consultative instances about their need of protection, particularly the local elected politicians, industries and civil societies within the CDNPS. Furthermore, these two colleges in the CDPNS may also advise on the juridical proceedings of "Site classé" in the formation of "Sites et paysages" and on studies of environmental impact of quarries in the formation "Carrière". The latter would allow geologists to guide quarry operators so that they take into account geological patrimony in their project plans.

\section{Conclusion}

The APPG is the only tool to-date adapted solely to the protection of geological heritage against local threats in France, yet its legal procedure is unexpectedly lengthy and convoluted, which can compromise the sites under imminent threats that it aims to protect. Currently, the French juridical system still does not permit to protect geological heritage in case of emergency. As long as geological objects are not taken into account in the project plans of urban developments - as biodiversity, landscapes and archaeological heritage are (article L122-1 of the Code of Environment) - the geodiversity of France remains threatened by fast-evolving anthropic actions. To avoid this, we suggest that preventive diagnostics of geological objects are carried out prior to any urban work, and protective or compensatory measures must be envisaged in case of unplanned geological discoveries. Since the law of 27 th of February 2002, which recognises geological heritage as part of natural heritage, Earth Sciences specialists have more possibilities to interfere in favour of geological heritage. Geologists and amateurs have a new part to play in the consultative bodies of local territories (e.g., CRPG, CSRPN, CDNPS) and contribute to a "grassroot democracy". Finally, it should be kept in mind that the legal protection of a geological site is only the first step of its conservation process; greater security will come about when actions of management are put into place, and will thus require supplementary regulatory tools like RNR or RNN. In the absence of successfully enacted APPG to date, this article can only remain hypothetical about the applications, benefits and drawbacks of this regulatory tool. In the future, when case laws will have grown in numbers, it will be possible to ascertain if the APPG truly fulfilled the scientific demand to protect a rich and representative geological patrimony in France.

Acknowledgements. The authors thank editor Laurent Jolivet and the anonymous reviewer for their constructive comments. We thank Sarah Garcia and Stéphane Lucet from the DRIEE for their relevant advices regarding the administrative aspects of the APPG and the members of the CRPG Île-de-France for 
their constructive remarks. Lucía Cordero Espinoza greatly improved this paper thanks to her careful work of translation, especially concerning the administrative terminology. This paper is a contribution to the project: “Appui à l'Inventaire du Patrimoine Géologique francilien" (Help to the Inventory of geological heritage of Île-de-France region) co-financed by the Regional Council of the Île-de-France and the DRIEE.

\section{References}

Abrard R. 1925. Le Lutétien du Bassin de Paris: essai de monographie stratigraphique. Angers: Société française d'imprimerie d'Angers, $383 \mathrm{p}$.

Alimen H. 1936. Étude sur le Stampien du bassin de Paris. Mémoires de la Société géologique de France 31: 1-309.

Avoine J. 2012. La protection du patrimoine géologique en France: bilan et perspectives. Annales de la Société Géologique du Nord 2 (19): 67-74.

Bétard F. 2015. Protection et valorisation du patrimoine géomorphologique en Île-de-France (Bassin de Paris, France) : État des lieux et perspectives. Vertigo, la Revue Électronique en Sciences de l'Environnement 15(1): 1-26. Doi: 10.4000/vertigo.16115.

Billet P. 2002. La protection du patrimoine géologique, guide juridique. Montpellier: ATEN, Cahiers techniques, vol. 67, 148 p.

Blondeau A. 1965. Le Lutétien des Bassins de Paris, de Belgique et du Hampshire: étude sédimentologique et paléontologique. Thèse d'État, Faculté des Sciences, Paris, 466 p.

Caze B. 2010. Intérêt systématique des motifs colorés résiduels chez les mollusques (Mollusca) du Cénozoïque d'Europe. Thèse de doctorat, Muséum national d'Histoire naturelle, Paris, 500 p.

Cuvier G, Brongniart A. 1811. Essai sur la géographie minéralogique des environs de Paris, avec une carte géognostique et des coupes de terrain. Paris : Institut Impérial de France, 278 p.

De Wever P, Egoroff G, Cornée A, Lalanne A. 2014. Géopatrimoine en France. Mémoires Hors-Série de la Société géologique de France 14: 1-180.

De Wever P, Alterio I, Egoroff G, Cornée A, Bobrowsky P, Collin G, et al. 2015. Geoheritage, a national inventory in France. Geoheritage 7(3): 205-247. Doi: 10.1007/s12371-015-0151-2.

Deshayes GP, Milne Edwars H. 1835. Histoire naturelle des animaux sans vertèbres, présentant les caractères généraux et particuliers de ces animaux, leur distribution, leurs classes, leurs familles, leurs genre, et la citation des principales espèces qui s'y rapportent; précédé d'une introduction. Paris : Baillière, $2^{\mathrm{e}}$ édition, tome $6,600 \mathrm{p}$.

Egoroff G, De Wever P, Cornee A, Monod K. 2011. Du Grenelle 1 à la protection du patrimoine géologique. Géochronique 119: 17-19.

Fritel PH. 1910. Guide géologique et paléontologique de la région parisienne dans un rayon de 100 kilomètres. Paris : Deyrolle, $359 \mathrm{p}$.

Gray M. 2004. Geodiversity, valuing and conserving abiotic nature. Chichester (England): John Wiley \& Sons, 371 p.

Hébert E. 1849. Compte rendu de la Réunion extraordinaire à Epernay (Marne). Bulletin de la Société géologique de France 2(6): 695-700.

Huyghe D, Merle D, Lartaud F, Cheype E, Emmanuel L. 2012. Middle Lutetian climate in the Paris Basin: implications for a marine hotspot of paleobiodiversity. Facies 58(4): 587-604.
Jonin M, Avoine J. 2010. Sites classés et patrimoine géologique. Géologie de la France 1: 19-23.

Lamarck JB. 1802-1809. Mémoires sur les fossiles des environs de Paris, comprenant la détermination des espèces qui appartiennent aux animaux marins sans vertèbres, et dont la plupart sont figurés dans la collection des vélins du Muséum. Annales du Muséum national d'Histoire naturelle, 1 (1802): 299-312, 383-391, 474 478; 2 (1803): 57-64, 163-169, 217-227, 315-321, 385-391; 3 (1804): 163-170, 266-274, 343-352, 436-441; 4 (1804): 46-55, 105-115, 212-222, 289-298, 429-436; 5 (1804): 28-36, 91-98, 179-188, 237-245, 349-357; 6 (1805): 117-126, 214-228, pls IIV, 337-345, 407-415; 7 (1806): 53-62, 130-139, 231244, pls VVII, 419-430; 8 (1806): 77-79, 156-166, 347355, 383-388, 461469, pls XVIII-XIV; 9 (1807): 236-240, 399-401, pls XV-XX; 12 (1808): 456-459, pls XXI-XXIV; 14 (1809): 374-375, pls XXVXXVIII.

Le Calvez Y. 1970. Contribution à l'étude des foraminifères paléogènes du bassin de Paris. Paris : Cahiers de paléontologie, CNRS, $326 \mathrm{p}$.

Le Calvez Y, Le Renard J. 1980. Paléontologie de deux célèbres gisements éocènes (Lutétien et Auversien) des environs de Paris. Compte rendu de l'excursion B-22. In: 26th international Geological Congress. Bulletin d'Information des Géologues du Bassin de Paris $\mathrm{n}^{\circ}$ hors-série: 1-8.

Linnaeus C. 1771. Mantissa Plantarum altera generum editionis VI et specierum editionis II. Salvii L., Holmiæ, 2, 587 p.

Merle D. 2008. Le Lutétien du bassin de Paris : un exemple de pointchaud de la paléodiversité. In: Merle D, ed. Stratotype Lutétien. Mèze : Biotope; Paris : MNHN, Orléans : BRGM, pp. 174-181.

Merle D, Auberger E, Gély J-P. 2016. Grignon (Lutétien, bassin de Paris) : «Terre sainte de la Science» paléontologique. Défendonsla! Fossiles 27: 5-18.

Ministère de L'Environnement, de l'Énergie et de la Mer, en charge des relations internationales sur le climat (MEEM). 2016. Note du $1^{\text {er }}$ décembre 2016 relative à la protection des sites d'intérêt géologique. NOR: DEVL1618949N, (Texte non paru au journal officiel). Disponible sur http://circulaire.legifrance.gouv.fr/ (last consult: 27/09/2017).

Morellet L, Morellet J. 1948. Le Bartonien du Bassin de Paris. Mémoires pour servir à l'explication de la carte géologique détaillée de la France. Paris : Imprimerie nationale, 437 p.

Neige P, Lapierre H, Merle D. 2016. New Eocene Coleoid (Cephalopoda) diversity from Statolith remains: taxonomic assignation, fossil record analysis, and new data for calibrating molecular phylogenies. Plosone 11(5): 1-24. Doi: 10.1371/journal. pone. 0154062 .

Pomerol C, Feugueur L. 1968. Bassin de Paris. Île-de-France, Pays de Bray. Paris: Masson, Guides géologiques régionaux, 215 p.

Réserves Naturelles de France. 2017. Available from http://www. reserves-naturelles.org/ (last consult: 2017/05/09).

Sanders MT, Merle D, Villier L. 2015. The molluscs of the «Falunière» of Grignon (Middle Lutetian, Yvelines, France): quantification of lithification bias and its impact on the biodiversity assessment of the Middle Eocene of Western Europe. Geodiversitas 37(3): 345-365. Available from https://doi.org/10.5252/ g2015n3a4.

Cite this article as: Auberger E, Gély J-P, Merle D. 2018. New regulatory tool for the conservation of the geological heritage in France: the Prefectural Decree of the Protection of the Geotope (APPG). Application and feedback in the Yvelines department (Paris basin, Île-deFrance), BSGF - Earth Sciences Bulletin 189: 3. 